\title{
Spirochetal Lipoproteins and Immune Evasion
}

\author{
Alexei Christodoulides, Ani Boyadjian and Theodoros Kelesidis* \\ David Geffen School of Medicine at University of California Los Angeles, Los Angeles, CA, USA
}

Spirochetes are a major threat to public health. However, the exact pathogenesis of spirochetal diseases remains unclear. Spirochetes express lipoproteins that often determine the cross talk between the host and spirochetes. Lipoproteins are pro-inflammatory, modulatory of immune responses, and enable the spirochetes to evade the immune system. In this article, we review the modulatory effects of spirochetal lipoproteins related to immune evasion. Understanding lipoprotein-induced immunomodulation will aid in elucidating innate pathogenesis processes and subsequent adaptive mechanisms potentially relevant to spirochetal disease vaccine development and treatment.

Keywords: spirochetes, lipoproteins, evasion mechanism, immune system, immunity

\section{OPEN ACCESS}

Edited by:

Maria Gomes-Solecki, University of Tennessee Health Science Center, USA

Reviewed by: Paulo Lee Ho, Butantan Institute, Brazil Roland Lang, University Hospital Erlangen, Germany

${ }^{*}$ Correspondence:

Theodoros Kelesidis tkelesidis@mednet.ucla.edu

Specialty section: This article was submitted to Microbial Immunology, a section of the journal

Frontiers in Immunology

Received: 13 November 2016 Accepted: 14 March 2017 Published: 29 March 2017

Citation:

Christodoulides A, Boyadjian A and Kelesidis T (2017) Spirochetal Lipoproteins and Immune Evasion.

Front. Immunol. 8:364. doi: 10.3389/fimmu.2017.00364

\section{INTRODUCTION}

Spirochetes cause many human diseases such as syphilis, Lyme disease, and leptospirosis that pose major threats to public health (1). Epidemiological studies have shown that the incidence of Lyme disease $(2-4)$, syphilis $(5-7)$, and leptospirosis $(8,9)$ have increased, both within United States and globally $(10,11)$. However, the immunopathogenesis of spirochetal diseases remains unclear (12-14). Despite the apparent immune response generated following spirochete infection (i.e., tissue inflammation) (15), spirochetes are known to persist in their host (16) through a wide variety of mechanisms ranging from a dynamic outer membrane capable of antigenic variation in the presence of outer-surface proteins capable of inhibiting macrophage facilitated phagocytosis $(17,18)$.

A critical question is what cellular components can trigger the strong immune responses that are characteristic of spirochetal infections. Spirochetal membranes play a pivotal role in interacting with a host's immune system $(19,20)$. Bacterial components such as lipopolysaccharides (LPSs) often play a major role in the induction of inflammation in bacterial infections $(21,22)$. Interestingly, aggressive immune responses are often observed despite the lack of LPS (endotoxin) in particular spirochetes, such as Borrelia burgdorferi $(19,23-25)$. Certain spirochetes such as Treponema pallidum, the spirochete responsible for syphilis, rely greatly on their ability to express adhesins over the surface of their membrane as a tool with which they can invade various tissues (26). Lipids compose $25-30 \%$ of a cell's dry weight $(19,20)$. Detergent treatments of spirochetal membranes have confirmed that lipoproteins are the most abundant in number out of all proteins expressed by spirochetes (27-32) and are major integral spirochetal membrane proteins $(27,33)$. For example, B. burgdorferi species express $>100$ lipoproteins (34) and Leptospira spp. have $>140$ lipoprotein genes (35). Although numerous examples of spirochetal lipoproteins can be listed, a few prominent ones include OspA from B. burgdorferi, Tp47 from T. pallidum, and Lip32 from the Leptospira species (36-38). The number of bacterial lipoproteins that have been studied parallels the myriad of roles that lipoproteins play in bacteria such as envelope biogenesis, stress responses, pathogenicity, and nutrient transport (39-41). 
However, there is limited evidence regarding the interplay between lipoproteins and human immune responses, partly due to the fact that in vitro studies do not accurately reflect human models. Understanding lipoprotein-induced immunomodulation will aid in elucidating innate pathogenesis processes and subsequent adaptive mechanisms potentially relevant to spirochetal disease vaccine development and treatment. In this article, we review the scientific evidence regarding the modulatory effects of spirochetal lipoproteins related to immune activation and evasion.

\section{MODULATORY EFFECTS OF SPIROCHETAL LIPOPROTEINS RELATED TO ACTIVATION OF THE IMMUNE SYSTEM}

Understanding the dualistic roles (activation vs inhibition) of lipoproteins in their interaction with the immune system is pivotal (42). Thus, before we explore mechanisms of spirochetal immune evasion, a better understanding of all the regulatory mechanisms (such as pro-inflammatory effects and immune activation) of spirochetal lipoproteins is needed. Better understanding of spirochetal lipoproteins and their regulatory mechanisms may provide insight into clinical outcomes arising from spirochetal infections. For example, spirochetal infections may increase the risk of Alzheimer's disease (43).

\section{Spirochetal Lipoproteins Induce Pro-inflammatory Effects}

One of the primary manifestations of spirochetal infection is tissue inflammation that is the mainstay of spirochetal diseases such as Lyme neuroborreliosis $(22,29)$. Spirochetal lipoproteins are known to induce strong pro-inflammatory responses in their hosts $(27,33,34,44-52)$ that comprise the initial innate immune response to the invading pathogen (49). Components of the inflammatory infiltrate include keratinocytes, macrophages, leukocytes, and cells capable of responding to the presence of lipoproteins (53-55). A better understanding of the modulatory effects of spirochetal lipoproteins in myeloid and non-myeloid immune cells is needed.

\section{Spirochetal Lipoproteins Have Modulatory Effects on Neutrophils}

Neutrophils have a major role in the immunopathogenesis of acute bacterial infections. Spirochetal lipoproteins, such as OspB, have been documented to inhibit neutrophil function and prevent oxidative burst in a variety of tissues, to prolong host infection (56-58). However, other lipoproteins can promote neutrophil activation. For example, OspA, even when presented at picomolar concentrations, has been seen to play a role in the activation of neutrophils and their chemotaxic capabilities $(51,59)$. Subsequent to neurophil activation, neutrophil tissue infiltration contributes to localized tissue inflammation that is pre-dominant in inflamed arthritic joints and in myocarditis (associated with spirochetal infections) $(50,51,60)$. In addition to mediating inflammatory responses, spirochetes, such as Leptospira, may induce neutrophils extracellular traps, which are a relatively novel pathogen-killing mechanism for extracellular microbes independent of phagocytic uptake and degranulation (61). Thus, spirochetal lipoproteins can modulate the function of neutrophils that are recruited early in acute inflammatory responses.

\section{Spirochetal Lipoproteins Have Pleotropic Modulatory Effects on Monocytes and Macrophages (M/M) That Are Mediated through Several Pathways}

Except for neutrophils, M/M also play a major role in spirochetal immunopathogenesis. Lipoproteins bind CD14 in the membrane of $\mathrm{M} / \mathrm{M}$ at the CD14 site that also interacts with LPS (62-64). This interaction activates the NF- $\mathrm{\kappa B}$ pathway and induces proinflammatory responses $(62,63,65)$. In addition, unlike the membrane-bound CD14, soluble CD14 also allows the activation of non-myeloid cells (66). Furthermore, the pro-inflammatory effects of spirochetal lipoproteins are often mediated by tolllike receptors (TLR) (67-69). TLR signaling leads to increased production of numerous cytokines that induce pro-inflammatory responses $(25,47)$. Interestingly, TLR-deficient mice had exacerbated inflammation and increased spirochetal burdens, both of which were attenuated by impairing $\mathrm{T}$ cell responses (70). As a bodily response to the vast amounts of pro-inflammatory cytokines produced upon spirochetal lipoprotein presence, monocytes have also been seen to produce IL-10 upon being presented with $B$. burgdorferi lipoproteins (71-75). IL-10, unlike cytokines such as IL-1 and IL-12, is known to reduce inflammation via TLR-pathway downregulation and can therefore assist in combatting the spirochetal infection as well as any possible chronic effects such as arthritis $(76,77)$. The above was confirmed in recent mice studies that utilized a TLR2 agonist, Pam3CSK4, to induce IL-10 production which attenuated inflammatory response to Leptospira (78). Thus, spirochetal lipoproteins exert their proinflammatory effects through several pathways including CD14, TLR, and NF- $\mathrm{KB}$ signaling and induce both pro-inflammatory (such as IL-1) and anti-inflammatory cytokines (IL-10) production in myeloid cells such as M/M.

\section{Spirochetal Lipoproteins Induce Activation of Dendritic Cells}

Similar to the activation of neutrophils, M/M, spirochetes also maintain the ability to activate other myeloid cells such as dendritic cells, key components in linking both the innate and adaptive immune system. Spirochetes activate cell adhesion molecules such as intercellular adhesion molecule 1 (ICAM-1), which then facilitate T-cell interactions and subsequent dendritic cell migration to lymph nodes for the mounting of an immune response $(79,80)$. In early stages of inflammation, lipoproteins in T. pallidum upregulate ICAM-1 and activate dendritic cells to mount immune responses $(25,46,49,81-84)$. Immune activation can also be induced upon spirochetal death or phagocytosis of spirochetes, both processes of which lead to further introduction of lipoproteins to the surrounding environment (80). The modulatory effects of spirochetal lipoproteins on dendritic cells are particularly important since dendritic cells play a major role in vaccine responses (discussed below). 


\section{Chronic Modulatory Effects of Spirochetal Lipoproteins and Effects on Adaptive Immunity May Drive Pathogenesis of Spirochetal Diseases}

Spirochetal lipoproteins may also play a role in the transition from the acute immune responses to the more chronic effects that characterize spirochetal diseases such as arthritis, peripheral neuropathy, numerous neurologic manifestations, and the vascular endothelial damage thought to underlie a significant portion of the chronic symptoms in spirochetal diseases (85-89). Although the exact mechanism of transition may not be well understood, lipoproteins may activate B-cells and T-cells, both of which are known to play major roles in long-term adaptive immunity (46, 47, 49-52). Further understanding of the exact transition process has major potential in terms of possibly delaying, or inhibiting, many of the debilitating chronic effects characteristic of numerous spirochetal infections.

\section{MODULATORY EFFECTS OF SPIROCHETAL LIPOPROTEINS RELATED TO FACILITATION OF IMMUNE EVASION}

Spirochetes evade a host's immune system through mechanisms such as antigenic variation, which is capable of producing myriads of variants (90). Spirochetal interference of the innate immune system presents one more mechanism, in a list of many, to allow for the persistence of spirochetes in their host $(16,91)$. Spirochetes use multiple mechanisms of immune evasion that are related to spirochetal lipoproteins. Indeed, except for pro-inflammatory effects, lipoproteins are also responsible for modulatory effects such as immune evasion. Spirochetes may limit the expression of membrane lipoproteins and their access to antibodies (92, 93) or induce antigenic variation of surface lipoproteins $(19,90$, 94-100). Spirochetal lipoproteins may also interact with, and inhibit, components of innate immunity such as the complement (63, 68, 88, 101-108), neutrophils, and serum lipoproteins (109). Major pathways of spirochetal immune evasion are discussed below (see also Table 1 and Figure 1) (110-130).

\section{Differential Dynamics of Spirochetal Lipoprotein Expression As a Mechanism of Immune Evasion}

The expression of lipoproteins on the outer leaflet of the membrane allows the spirochete to interact with tissues and the host's immune system (110). Naturally, the vast abundance of lipoproteins a given spirochete can express are not all necessary at a given time point, and their expression is time sensitive (111). Although more work is needed to elucidate the time-sensitive expression of surface lipoproteins, studies have hinted at the possibility of a temperature-sensitive mechanism to underlie expression patterns (112). For example, OspA in B. burgdorferi is not needed upon host infection and is therefore downregulated upon infection of a host via a temperature-sensitive alteration in membrane composition (111). Coupled closely with the need of a lipoprotein to be expressed on the exterior of the cell for interactions to
TABLE 1 | Mechanisms of immune evasion of major spirochetal lipoproteins.

\begin{tabular}{ll}
\hline Bacteria & Role in immune evasion \\
\hline Borrelia burgdorferi & Antigenic variation [VIsE proteins (118, 120, 131-134), \\
& OspC (135)] \\
& Evasion of complement-mediated lysis [OspE, Erp \\
& $(136-138)$, CspA (139)] \\
& Impairment of neutrophil function (BBA57) (140)
\end{tabular}

Oral treponemes (ex. C3b inactivation (various lipoproteins) (141)

Treponema denticola)

Borrelia recurrentis

Antigenic variation (variable large and small protein genes and Vmp variants) $(19,110)$

Bind to complement regulatory proteins, i.e., CFH and CFHR-1 [FhbA, BhCRASP-1, and HcpA (142-145)]

Borrelia turicatae

Antigenic variation (variable large and small protein genes and Vmp variants) $(19,110)$

Inhibit C4bp and C1-Inh, the major inhibitors of the classical and lectin pathway of complement activation (CihC) (146)

Binds to human complement regulators, Factor $\mathrm{H}$, CFHR-1 (HcpA) (143)

Borrelia hermsii

Antigenic variation (variable large and small protein genes and Vmp variants) $(19,110)$

Bind to complement regulatory proteins, i.e., $\mathrm{CFH}$ and CFHR-1 [FhbA, BhCRASP-1, and HcpA (142-145)]

Leptospira interrogans Impairment of neutrophil function (LIC11207) (147) Bind to complement regulators (LigA, LigB, Len A, Len B) (148)

Antigenic variation in borrelias may result from recombination of variable large and small protein genes. Lipoproteins may also impair mechanisms of innate immunity such as neutrophil function and complement activation. These mechanisms allow the spirochete to evade the host's immune response and persist in the mammalian host. BBA57, Borrelia burgdorferi A57 protein; BhCRASP-1, Borrelia hermsii complement regulator-acquiring surface protein 1; C1-Inh, human $C 1$ esterase inhibitor;

CihC, C1-inhibitor and C4bp-binding protein; C4bp, C4b-binding protein; CspA, complement regulator-acquiring surface protein-1; Erp, OspE-F-related lipoprotein; FhbA, complement factor $\mathrm{H}$-binding protein; HcpA, human complement regulator and plasminogen-binding protein; LIC11207, L. interrogans serovar Copenhageni (LIC) protein 11207; LigA, leptospiral immunoglobulin-like protein A; LigB, leptospiral immunoglobulin-like protein B; OspC, outer-surface protein C; OspE, outer-surface protein E; VIsE, variable major protein-like sequence E; Vmp, variable major lipoprotein.

occur, the lipoprotein must maintain its $\mathrm{N}$-terminus as it has been documented that it is this region specifically to which immune system-spirochete interactions occur $(113,114)$. In line with the above statement, removal of the N-terminus disrupts the aforesaid interactions while synthesis of $\mathrm{N}$-terminus analogs restored immune cell activation $(114,115)$. The limitation of outer-membrane lipoprotein expression in spirochetes may also act as a mechanism to facilitate host humoral defense evasion. Antibody recognizable lipoproteins may be scarcely expressed on the exterior leaflets, as opposed to the relatively more lipoprotein dense cytoplasmic leaflet $(92,93,116)$. Further studies are needed to elucidate the role of differential dynamics of spirochetal lipoprotein expression in spirochetal immunopathogenesis.

\section{Antigenic Variation of Surface Lipoproteins}

Coupled with the limited expression of outer-membrane lipoproteins in spirochetes, antigenic variation is a major mechanism 


\section{Spirochetal lipoproteins}

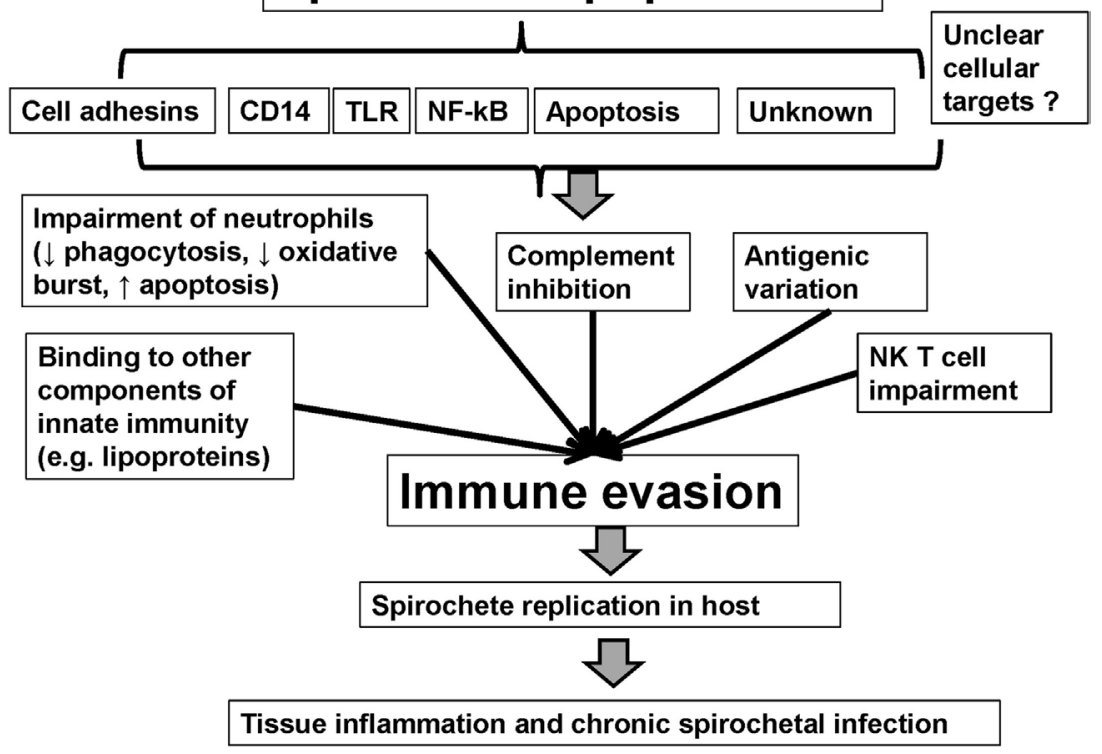

FIGURE 1 | Mechanisms of immune evasion mediated by spirochetal lipoproteins.

by which invading bacteria can evade the host immune response (117). Spirochetes also undergo a process of antigenic variation in terms of expressed outer-leaflet lipoproteins $(96,118)$. Studies in immunocompromised hosts have suggested that the host immune responses have a major role in producing spirochetal antigenic variants (96). Antigenic variation in borrelias may result from recombination of variable large and small protein genes (98) and the diversity of variable major lipoprotein lipoproteins allows these pathogens to evade the host immune response (19, 23, 119). Moreover, outer-leaflet lipoprotein variation also allows spirochetal adherence to a wide variety of host cells, as studies of T. pallidum TP0435 isoforms have recently shown (26). The antigenic variation of major surface lipoproteins is described in Table 1 (19, 90, 94-100).

The ability to vary surface lipoprotein expression has been studied in B. burgdorferi, where it has been shown that prolonged infections are due to the embodiment of a $v l s$ locus that is capable of random segmental variation in the surface-exposed lipoprotein it encodes $(118,120)$. The $v l s$ locus variation specifically allows for the variation in the encoded variable major proteinlike sequence lipoprotein which has been documented to allow for persistence of B. burgdorferi in its host (120). The antigenic variation of spirochetes leads to evasion of the immune system and ultimately to the phenomenon of host relapsing (121). Most interestingly, antigenic variation characteristic of B. burgdorferi is only seen during host infection. Spirochetal antigenic variation has not been described in vitro. Thus, the cross talk between host cellular responses and B. burgdorferi is needed for development of antigenic variation (perhaps through downregulation of OspA) (96). Elimination of the ability to undergo antigenic variation, as was done in Borrelia hermsii, may greatly reduce host infectivity/ persistence (119). Understanding the exact mechanisms behind a spirochete's ability to elicit immune evasion via antigenic variation could set the basis for targeted interventions to inhibit infections (122).

\section{Inhibition of Neutrophil Function by Spirochetes}

Neutrophil-mediated phagocytosis of pathogens is a major host immune response to infection. Thus, spirochetes evade immune responses by inactivating neutrophil function (56). The most prominent examples of the above can be seen with the B. burgdorferi surface protein $\mathrm{OspB}$, which may prevent phagocytosis of the spirochete and inhibit respiratory/oxidative burst in a variety of tissues, such as the skin (56-58). It should be noted that $B$. burgdorferi also contains outer-surface protein $\mathrm{C}$ which plays a role in inhibiting phagocytosis by macrophages (18). Similar to OspB that impairs neutrophil function, the novel lipoprotein Leptospira interrogans serovar Copenhageni (LIC) protein 11207 from Leptospira, promotes apoptotic pathways in neutrophils (123). Thus, spirochetal lipoproteins can both activate and impair neutrophils.

\section{Lipoprotein Inhibition of Complement Activation}

One of the major components of a host's innate immune system is the complement system that plays a role in the phagocytosis/elimination of a pathogen and is a target of spirochetes upon infection (124). Activation of the complement system is known to occur through the recognition of surface-exposed lipoproteins as well as other antigens such as oligosaccharides (124). The multi-stage process of complement activation presents spirochetes (such as $B$. burgdorferi) with the opportunity to attack at multiple phases. For example, $B$. burgdorferi binds and inhibits the $\mathrm{C} 1$ initiation 
complex and accelerates C3b inactivation $(91,125)$. Furthermore, B. burgdorferi can bind either Factor H or FHL-1, two important complement regulators which upon being bound by CRASP-2 and CRASP-1 (B. burgdorferi membrane-bound lipoproteins), respectively, are inactivated and inhibit formation of complement system activation products $(126,127)$. B. burgdorferi also maintains the ability to bind factor $\mathrm{H}$, via particular Osp, such as outer-surface protein E, accomplishing the same outcome as with CRASP-2 binding (128). Hijacking of the complement system is a conserved mechanism of immune evasion among numerous pathogens (such as Plasmodium falciparum) (129). Therefore, understanding the mechanisms behind complement hijacking in spirochetes could potentially contribute to understanding conserved pathways in other pathogens.

\section{Lipoprotein Inhibition of Natural Killer T (NKT) Cells}

Natural killer (NK) cells act to bridge the innate and adaptive immune responses to pathogenic infections; however, it is their ability to respond to a variety of lipid antigens that allows them to maintain a functional presence during combat of spirochetal infections (130). Spirochetes are capable of interfering with the NKT cells that respond to CD1d glycolipids on the surface of spirochetes such as B. burgdorferi (149). Although the exact biochemical pathway of interference is not well understood, patients with syphilis have been known to exhibit low NKT numbers (150). Further studies are needed to understand the possible interaction between spirochetal lipoproteins and NK cells.

\section{UNDERSTANDING LIPOPROTEIN- MEDIATED PATHWAYS OF IMMUNE EVASION MAY PAVE THE WAY FOR DEVELOPMENT OF STRATEGIES TO TREAT SPIROCHETAL INFECTIONS}

Understanding the pleotropic modulatory effects of lipoproteins may contribute to the development of new approaches to combat a plethora of diseases (151-154). Use of adjuvants in vaccines may enhance recognition of whole proteins by the adaptive immune system $(151,155)$. The immunopotent effects of spirochetal

\section{REFERENCES}

1. Steere AC. Lyme disease. N Engl J Med (2001) 345(2):115-25. doi:10.1056/ NEJM200107123450207

2. Stricker RB, Johnson L. Lyme disease: the promise of big data, companion diagnostics and precision medicine. Infect Drug Resist (2016) 9:215-9. doi:10.2147/IDR.S114770

3. Bacon RM, Kugeler KJ, Mead PS; Centers for Disease Control and Prevention (CDC). Surveillance for Lyme disease - United States, 1992-2006. MMWR Surveill Summ (2008) 57(10):1-9.

4. Centers for Disease, Control and Prevention. Lyme disease - United States, 2003-2005. MMWR Morb Mortal Wkly Rep (2007) 56(23):573-6.

5. Centers for Disease, Control and Prevention. Primary and secondary syphilis United States, 1999. MMWR Morb Mortal Wkly Rep (2001) 50(7):113-7.

6. Centers for Disease, Control and Prevention. Primary and secondary syphilis - United States, 2003-2004. MMWR Morb Mortal Wkly Rep (2006) 55(10):269-73. lipoproteins have hinted at the possibility for the development of vaccines that rely on the use of synthetic or derived lipopeptides (151, 155, 156). Spirochetal lipoproteins, such as OspA, can be expressed on the surface of outer-membrane vesicles to elicit an immune response similar to vaccines (157). Improvements in recombinant bacterial lipoprotein generation promise to make lipopeptide-based vaccines more feasible in the near future (158). The incorporation of numerous epitopes, such as lipoproteins, as adjuvants into vaccines can help target various diseases including cancer $(155,159)$. On the other hand, incorporation of a lipid moiety in peptide-based vaccines may induce TLR2 signaling in dendritic cells and subsequent protection against viral and bacterial infections (156). Finally, the use of lipopeptide-based antibiotics such as daptomycin, that can cause both immunomodulation (160) and also target spirochetes (161), remains to be studied as a therapeutic option for patients with spirochetal infections.

\section{CONCLUSION}

Lipoproteins play a significant role in the various stages of a spirochete's ability to infect a host and survive, through pleotropic effects involving transfer from vector to host, immune activation, or even immune evasion. Further studies are needed to understand the molecular basis and mechanisms that underpin the numerous modulatory effects (both acute and chronic) of spirochetal lipoproteins. The payout from such targeted research can be significant considering the sheer amount of spirochetal infections occurring on a yearly basis as well as the morbidity associated with chronic spirochetal infections in humans. Ultimately, the use of knowledge surrounding spirochetal lipoproteins can be put toward the development of vaccines or, perhaps shed light on the pathogenesis of other vector-based pathogens.

\section{AUTHOR CONTRIBUTIONS}

$\mathrm{AC}, \mathrm{AB}$, and TK contributed to writing of this manuscript.

\section{FUNDING}

This work was supported by NIH grants NIH K08AI08272 and NIH/NCATS Grant \# UL1TR000124.

7. Centers for Disease, Control and Prevention. Primary and secondary syphilis - United States, 2000-2001. MMWR Morb Mortal Wkly Rep (2002) 51(43):971-3.

8. Bharti AR, Nally JE, Ricaldi JN, Matthias MA, Diaz MM, Lovett MA, et al. Leptospirosis: a zoonotic disease of global importance. Lancet Infect Dis (2003) 3(12):757-71. doi:10.1016/S1473-3099(03)00830-2

9. Victoriano AF, Smythe LD, Gloriani-Barzaga N, Cavinta LL, Kasai T, Limpakarnjanarat $\mathrm{K}$, et al. Leptospirosis in the Asia Pacific region. BMC Infect Dis (2009) 9:147. doi:10.1186/1471-2334-9-147

10. Ostfeld RS, Brunner JL. Climate change and Ixodes tick-borne diseases of humans. Philos Trans R Soc Lond B Biol Sci (2015) 370(1665):20140051. doi:10.1098/rstb.2014.0051

11. Kaffenberger BH, Shetlar D, Norton SA, Rosenbach M. The effect of climate change on skin disease in North America. J Am Acad Dermatol (2016) 76(1):140-7. doi:10.1016/j.jaad.2016.08.014

12. Steere AC, Coburn J, Glickstein L. The emergence of Lyme disease. J Clin Invest (2004) 113(8):1093-101. doi:10.1172/JCI21681 
13. Hook EW III, Peeling RW. Syphilis control - a continuing challenge. N Engl $J$ Med (2004) 351(2):122-4. doi:10.1056/NEJMp048126

14. Duray PH. Histopathology of clinical phases of human Lyme disease. Rheum Dis Clin North Am (1989) 15(4):691-710.

15. Chaaya G, Jaller-Char JJ, Ali SK. Beyond the bull's eye: recognizing Lyme disease. J Fam Pract (2016) 65(6):373-9.

16. Radolf JD, Deka RK, Anand A, Šmajs D, Norgard MV, Yang XF. Treponema pallidum, the syphilis spirochete: making a living as a stealth pathogen. Nat Rev Microbiol (2016) 14(12):744-59. doi:10.1038/nrmicro.2016.141

17. Radolf JD, Desrosiers DC. Treponema pallidum, the stealth pathogen, changes, but how? Mol Microbiol (2009) 72(5):1081-6. doi:10.1111/j.13652958.2009.06711.x

18. Carrasco SE, Troxell B, Yang Y, Brandt SL, Li H, Sandusky GE, et al. Outer surface protein $\mathrm{OspC}$ is an antiphagocytic factor that protects Borrelia burgdorferi from phagocytosis by macrophages. Infect Immun (2015) 83(12):4848-60. doi:10.1128/IAI.01215-15

19. Haake DA. Spirochaetal lipoproteins and pathogenesis. Microbiology (2000) 146(Pt 7):1491-504. doi:10.1099/00221287-146-7-1491

20. Hossain H, Wellensiek HJ, Geyer R, Lochnit G. Structural analysis of glycolipids from Borrelia burgdorferi. Biochimie (2001) 83(7):683-92. doi:10.1016/ S0300-9084(01)01296-2

21. Ulevitch RJ, Tobias PS. Recognition of gram-negative bacteria and endotoxin by the innate immune system. Curr Opin Immunol (1999) 11(1):19-22. doi:10.1016/S0952-7915(99)80004-1

22. Ramesh G, Meisner OC, Philipp MT. Anti-inflammatory effects of dexamethasone and meloxicam on Borrelia burgdorferi-induced inflammation in neuronal cultures of dorsal root ganglia and myelinating cells of the peripheral nervous system. J Neuroinflammation (2015) 12:240. doi:10.1186/ s12974-015-0461-y

23. Schröder NW, Eckert J, Stübs G, Schumann RR. Immune responses induced by spirochetal outer membrane lipoproteins and glycolipids. Immunobiology (2008) 213(3-4):329-40. doi:10.1016/j.imbio.2007.11.003

24. Rietschel ET, Schletter J, Weidemann B, El-Samalouti V, Mattern T, Zähringer $\mathrm{U}$, et al. Lipopolysaccharide and peptidoglycan: CD14-dependent bacterial inducers of inflammation. Microb Drug Resist (1998) 4(1):37-44. doi:10.1089/ mdr.1998.4.37

25. RadolfJD, Arndt LL, Akins DR, Curetty LL, Levi ME, Shen Y, et al. Treponema pallidum and Borrelia burgdorferi lipoproteins and synthetic lipopeptides activate monocytes/macrophages. J Immunol (1995) 154(6):2866-77.

26. Chan K, Nasereddin T, Alter L, Centurion-Lara A, Giacani L, Parveen N. Treponema pallidum lipoprotein TP0435 expressed in Borrelia burgdorferi produces multiple surface/periplasmic isoforms and mediates adherence. Sci Rep (2016) 6:25593. doi:10.1038/srep25593

27. Chamberlain NR, Brandt ME, Erwin AL, Radolf JD, Norgard MV. Major integral membrane protein immunogens of Treponema pallidum are proteolipids. Infect Immun (1989) 57(9):2872-7.

28. Liang FT, Nelson FK, Fikrig E. DNA microarray assessment of putative Borrelia burgdorferi lipoprotein genes. Infect Immun (2002) 70(6):3300-3. doi:10.1128/IAI.70.6.3300-3303.2002

29. Weis JJ, Ma Y, Erdile LF. Biological activities of native and recombinant Borrelia burgdorferi outer surface protein A: dependence on lipid modification. Infect Immun (1994) 62(10):4632-6.

30. Braun V, Hantke K. Biochemistry of bacterial cell envelopes. Annu Rev Biochem (1974) 43(0):89-121. doi:10.1146/annurev.bi.43.070174. 000513

31. Radolf JD, Chamberlain NR, Clausell A, Norgard MV. Identification and localization of integral membrane proteins of virulent Treponema pallidum subsp. pallidum by phase partitioning with the nonionic detergent triton X-114. Infect Immun (1988) 56(2):490-8.

32. Bricker TM, Boyer MJ, Keith J, Watson-McKown R, Wise KS. Association of lipids with integral membrane surface proteins of Mycoplasma hyorhinis. Infect Immun (1988) 56(2):295-301.

33. Brandt ME, Riley BS, Radolf JD, Norgard MV. Immunogenic integral membrane proteins of Borrelia burgdorferi are lipoproteins. Infect Immun (1990) 58(4):983-91.

34. Fraser CM, Norris SJ, Weinstock GM, White O, Sutton GG, Dodson R, et al. Complete genome sequence of Treponema pallidum, the syphilis spirochete. Science (1998) 281(5375):375-88. doi:10.1126/science.281.5375.375
35. Setubal JC, Reis M, Matsunaga J, Haake DA. Lipoprotein computational prediction in spirochaetal genomes. Microbiology (2006) 152(Pt 1):113-21. doi:10.1099/mic.0.28317-0

36. Deka RK, Machius M, Norgard MV, Tomchick DR. Crystal structure of the 47-kDa lipoprotein of Treponema pallidum reveals a novel penicillin-binding protein. J Biol Chem (2002) 277(44):41857-64. doi:10.1074/ jbc.M207402200

37. Toledo A, Pérez A, Coleman JL, Benach JL. The lipid raft proteome of Borrelia burgdorferi. Proteomics (2015) 15(21):3662-75. doi:10.1002/pmic.201500093

38. Wongbutdee J, Jittimanee J. Detection of Leptospira in rats trapped from households in Phraroj village, Muang Sam Sip district, Ubon Ratchathani province using polymerase chain reaction technique. J Med Assoc Thai (2016) 99(Suppl 1):S17-21.

39. Shahmirzadi SV, Nguyen MT, Gotz F. Evaluation of Staphylococcus aureus lipoproteins: role in nutritional acquisition and pathogenicity. Front Microbiol (2016) 7:1404. doi:10.3389/fmicb.2016.01404

40. Szewczyk J, Collet JF. The journey of lipoproteins through the cell: one birthplace, multiple destinations. Adv Microb Physiol (2016) 69:1-50. doi:10.1016/ bs.ampbs.2016.07.003

41. Narita SI, Tokuda H. Bacterial lipoproteins; biogenesis, sorting and quality control. Biochim Biophys Acta (2016). doi:10.1016/j.bbalip.2016.11.009

42. Grosenbaugh DA, Rissi DR, Krimer PM. Demonstration of the ability of a canine Lyme vaccine to reduce the incidence of histological synovial lesions following experimentally-induced canine Lyme borreliosis. Vet Immunol Immunopathol (2016) 180:29-33. doi:10.1016/j.vetimm.2016.08.014

43. Maheshwari P, Eslick GD. Bacterial infection and Alzheimer's disease: a meta-analysis. J Alzheimers Dis (2015) 43(3):957-66. doi:10.3233/JAD140621

44. Casjens S, Palmer N, van Vugt R, Huang WM, Stevenson B, Rosa P, et al. A bacterial genome in flux: the twelve linear and nine circular extrachromosomal DNAs in an infectious isolate of the Lyme disease spirochete Borrelia burgdorferi. Mol Microbiol (2000) 35(3):490-516. doi:10.1046/j.1365-2958.2000.01698.x

45. Fraser CM, Casjens S, Huang WM, Sutton GG, Clayton R, Lathigra R, et al. Genomic sequence of a Lyme disease spirochaete, Borrelia burgdorferi. Nature (1997) 390(6660):580-6. doi:10.1038/37551

46. Norgard MV, Arndt LL, Akins DR, Curetty LL, Harrich DA, Radolf JD. Activation of human monocytic cells by Treponema pallidum and Borrelia burgdorferi lipoproteins and synthetic lipopeptides proceeds via a pathway distinct from that of lipopolysaccharide but involves the transcriptional activator NF-kappa B. Infect Immun (1996) 64(9):3845-52.

47. Ma Y, Seiler KP, Tai KF, Yang L, Woods M, Weis JJ. Outer surface lipoproteins of Borrelia burgdorferi stimulate nitric oxide production by the cytokine-inducible pathway. Infect Immun (1994) 62(9):3663-71.

48. Ma Y, Weis JJ. Borrelia burgdorferi outer surface lipoproteins OspA and OspB possess B-cell mitogenic and cytokine-stimulatory properties. Infect Immun (1993) 61(9):3843-53.

49. Norgard MV, Riley BS, Richardson JA, Radolf JD. Dermal inflammation elicited by synthetic analogs of Treponema pallidum and Borrelia burgdorferi lipoproteins. Infect Immun (1995) 63(4):1507-15.

50. Wooten RM, Modur VR, McIntyre TM, Weis JJ. Borrelia burgdorferi outer membrane protein A induces nuclear translocation of nuclear factor-kappa B and inflammatory activation in human endothelial cells. J Immunol (1996) 157(10):4584-90.

51. Morrison TB, Weis JH, Weis JJ. Borrelia burgdorferi outer surface protein A (OspA) activates and primes human neutrophils. JImmunol (1997) 158(10):4838-45.

52. Gondolf KB, Mihatsch M, Curschellas E, Dunn JJ, Batsford SR. Induction of experimental allergic arthritis with outer surface proteins of Borrelia burgdorferi. Arthritis Rheum (1994) 37(7):1070-7. doi:10.1002/art.1780370713

53. Kupper TS, Fuhlbrigge RC. Immune surveillance in the skin: mechanisms and clinical consequences. Nat Rev Immunol (2004) 4(3):211-22. doi:10.1038/ nri1310

54. Pivarcsi A, Bodai L, Réthi B, Kenderessy-Szabó A, Koreck A, Széll M, et al. Expression and function of toll-like receptors 2 and 4 in human keratinocytes. Int Immunol (2003) 15(6):721-30. doi:10.1093/intimm/dxg068

55. Takeuchi J, Watari E, Shinya E, Norose Y, Matsumoto M, Seya T, et al. Downregulation of toll-like receptor expression in monocyte-derived Langerhans 
cell-like cells: implications of low-responsiveness to bacterial components in the epidermal Langerhans cells. Biochem Biophys Res Commun (2003) 306(3):674-9. doi:10.1016/S0006-291X(03)01022-2

56. Hartiala P, Hytönen J, Suhonen J, Leppäranta O, Tuominen-Gustafsson H, Viljanen MK. Borrelia burgdorferi inhibits human neutrophil functions. Microbes Infect (2008) 10(1):60-8. doi:10.1016/j.micinf.2007.10.004

57. van Burgel ND, Kraiczy P, Schuijt TJ, Zipfel PF, van Dam AP. Identification and functional characterisation of complement regulator acquiring surface protein-1 of serum resistant Borrelia garinii OspA serotype 4. BMC Microbiol (2010) 10:43. doi:10.1186/1471-2180-10-43

58. Sadziene A, Thomas DD, Barbour AG. Borrelia burgdorferi mutant lacking Osp: biological and immunological characterization. Infect Immun (1995) 63(4):1573-80.

59. Benach JL, Coleman JL, Garcia-Monco JC, Deponte PC. Biological activity of Borrelia burgdorferi antigens. Ann N Y Acad Sci (1988) 539:115-25. doi:10.1111/j.1749-6632.1988.tb31845.x

60. Detmer SE, Bouljihad M, Hayden DW, Schefers JM, Armien A, Wünschmann A. Fatal pyogranulomatous myocarditis in 10 Boxer puppies. J Vet Diagn Invest (2016) 28(2):144-9. doi:10.1177/1040638715626486

61. Scharrig E, Carestia A, Ferrer MF, Cédola M, Pretre G, Drut R, et al. Neutrophil extracellular traps are involved in the innate immune response to infection with Leptospira. PLoS Negl Trop Dis (2015) 9(7):e0003927. doi:10.1371/journal.pntd.0003927

62. Sellati TJ, Bouis DA, Kitchens RL, Darveau RP, Pugin J, Ulevitch RJ, et al. Treponema pallidum and Borrelia burgdorferi lipoproteins and synthetic lipopeptides activate monocytic cells via a CD14-dependent pathway distinct from that used by lipopolysaccharide. J Immunol (1998) 160(11):5455-64.

63. Wooten RM, Morrison TB, Weis JH, Wright SD, Thieringer R, Weis JJ. The role of CD14 in signaling mediated by outer membrane lipoproteins of Borrelia burgdorferi. J Immunol (1998) 160(11):5485-92.

64. Wright SD, Ramos RA, Tobias PS, Ulevitch RJ, Mathison JC. CD14, a receptor for complexes of lipopolysaccharide (LPS) and LPS binding protein. Science (1990) 249(4975):1431-3. doi:10.1126/science.1698311

65. Giambartolomei GH, Dennis VA, Lasater BL, Philipp MT. Induction of pro- and anti-inflammatory cytokines by Borrelia burgdorferi lipoproteins in monocytes is mediated by CD14. Infect Immun (1999) 67(1):140-7.

66. Ranoa DR, Kelley SL, Tapping RI. Human lipopolysaccharide-binding protein (LBP) and CD14 independently deliver triacylated lipoproteins to toll-like receptor 1 (TLR1) and TLR2 and enhance formation of the ternary signaling complex. J Biol Chem (2013) 288(14):9729-41. doi:10.1074/jbc. M113.453266

67. Hirschfeld M, Kirschning CJ, Schwandner R, Wesche H, Weis JH, Wooten RM, et al. Cutting edge: inflammatory signaling by Borrelia burgdorferi lipoproteins is mediated by toll-like receptor 2. JImmunol (1999) 163(5):2382-6.

68. Alexopoulou L, Thomas V, Schnare M, Lobet Y, Anguita J, Schoen RT, et al. Hyporesponsiveness to vaccination with Borrelia burgdorferi OspA in humans and in TLR1- and TLR2-deficient mice. Nat Med (2002) 8(8):878-84. doi:10.1038/nm732

69. Aliprantis AO, Yang RB, Mark MR, Suggett S, Devaux B, Radolf JD, et al. Cell activation and apoptosis by bacterial lipoproteins through toll-like receptor-2. Science (1999) 285(5428):736-9. doi:10.1126/science.285.5428.736

70. Lasky CE, Pratt CL, Hilliard KA, Jones JL, Brown CR. T cells exacerbate Lyme borreliosis in TLR2-deficient mice. Front Immunol (2016) 7:468. doi:10.3389/ fimmu.2016.00468

71. Giambartolomei GH, Dennis VA, Philipp MT. Borrelia burgdorferi stimulates the production of interleukin-10 in peripheral blood mononuclear cells from uninfected humans and rhesus monkeys. Infect Immun (1998) 66(6):2691-7.

72. Giambartolomei GH, Dennis VA, Lasater BL, Murthy PK, Philipp MT. Autocrine and exocrine regulation of interleukin-10 production in THP-1 cells stimulated with Borrelia burgdorferi lipoproteins. Infect Immun (2002) 70(4):1881-8. doi:10.1128/IAI.70.4.1881-1888.2002

73. Ganapamo F, Dennis VA, Philipp MT. Early induction of gamma interferon and interleukin-10 production in draining lymph nodes from mice infected with Borrelia burgdorferi. Infect Immun (2000) 68(12):7162-5. doi:10.1128/ IAI.68.12.7162-7165.2000

74. Häupl T, Landgraf S, Netusil P, Biller N, Capiau C, Desmons P, et al. Activation of monocytes by three OspA vaccine candidates: lipoprotein OspA is a potent stimulator of monokines. FEMS Immunol Med Microbiol (1997) 19(1):15-23. doi:10.1111/j.1574-695X.1997.tb01068.x

75. Murthy PK, Dennis VA, Lasater BL, Philipp MT. Interleukin-10 modulates proinflammatory cytokines in the human monocytic cell line THP-1 stimulated with Borrelia burgdorferi lipoproteins. Infect Immun (2000) 68(12):6663-9. doi:10.1128/IAI.68.12.6663-6669.2000

76. Gautam A, Dixit S, Philipp MT, Singh SR, Morici LA, Kaushal D, et al. Interleukin-10 alters effector functions of multiple genes induced by Borrelia burgdorferi in macrophages to regulate Lyme disease inflammation. Infect Immun (2011) 79(12):4876-92. doi:10.1128/IAI.05451-11

77. Lochhead RB, Zachary JF, Dalla Rosa L, Ma Y, Weis JH, O'Connell RM, et al. Antagonistic interplay between microRNA-155 and IL-10 during Lyme carditis and arthritis. PLoS One (2015) 10(8):e0135142. doi:10.1371/journal. pone. 0135142

78. Zhang W, Zhang N, Xie X, Guo J, Jin X, Xue F, et al. Toll-Like receptor 2 agonist Pam3CSK4 alleviates the pathology of leptospirosis in hamster. Infect Immun (2016) 84(12):3350-7. doi:10.1128/IAI.00708-16

79. Mason LM, Wagemakers A, van't Veer C, Oei A, van der Pot WJ, Ahmed $\mathrm{K}$, et al. Borrelia burgdorferi induces TLR2-mediated migration of activated dendritic cells in an ex vivo human skin model. PLoS One (2016) 11(10):e0164040. doi:10.1371/journal.pone.0164040

80. Bouis DA, Popova TG, Takashima A, Norgard MV. Dendritic cells phagocytose and are activated by Treponema pallidum. Infect Immun (2001) 69(1):518-28. doi:10.1128/IAI.69.1.518-528.2001

81. Akins DR, Purcell BK, Mitra MM, Norgard MV, Radolf JD. Lipid modification of the 17-kilodalton membrane immunogen of Treponema pallidum determines macrophage activation as well as amphiphilicity. Infect Immun (1993) 61(4):1202-10.

82. DeOgny L, Pramanik BC, Arndt LL, Jones JD, Rush J, Slaughter CA, et al. Solid-phase synthesis of biologically active lipopeptides as analogs for spirochetal lipoproteins. Pept Res (1994) 7(2):91-7.

83. Riley BS, Oppenheimer-Marks N, Hansen EJ, Radolf JD, Norgard MV. Virulent Treponema pallidum activates human vascular endothelial cells. J Infect Dis (1992) 165(3):484-93. doi:10.1093/infdis/165.3.484

84. Radolf JD, Norgard MV, Brandt ME, Isaacs RD, Thompson PA, Beutler B. Lipoproteins of Borrelia burgdorferi and Treponema pallidum activate cachectin/tumor necrosis factor synthesis. Analysis using a CAT reporter construct. J Immunol (1991) 147(6):1968-74.

85. Hansen ES, Johnson ME, Schell RF, Nardelli DT. CD4+ cell-derived interleukin-17 in a model of dysregulated, Borrelia-induced arthritis. Pathog Dis (2016) 74(7):ftw084. doi:10.1093/femspd/ftw084

86. Stricker RB, Johnson L. Borrelia burgdorferi aggrecanase activity: more evidence for persistent infection in Lyme disease. Front Cell Infect Microbiol (2013) 3:40. doi:10.3389/fcimb.2013.00040

87. Marques AR. Lyme neuroborreliosis. Continuum (Minneap Minn) (2015) 21 (6 Neuroinfectious Disease):1729-44. doi:10.1212/CON.0000000000000252

88. Salazar JC, Pope CD, Moore MW, Pope J, Kiely TG, Radolf JD. Lipoproteindependent and -independent immune responses to spirochetal infection. Clin Diagn Lab Immunol (2005) 12(8):949-58.

89. Bagautdinova LI, Platonov AE, Sarksyan DS, Stukolova OV, Shipulin GA, Maleev VV, et al. [Follow-up of patients with Ixodes tick-borne borrelioses caused by Borrelia miyamotoi or Borrelia burgdorferi sensu lato]. Ter Arkh (2016) 88(11):43-54. doi:10.17116/terarkh2016881143-54

90. Zhang JR, Hardham JM, Barbour AG, Norris SJ. Antigenic variation in Lyme disease borreliae by promiscuous recombination of VMP-like sequence cassettes. Cell (1997) 89(2):275-85. doi:10.1016/S0092-8674(00) 80206-8

91. Alitalo A, Meri T, Rämö L, Jokiranta TS, Heikkilä T, Seppälä IJ, et al. Complement evasion by Borrelia burgdorferi: serum-resistant strains promote C3b inactivation. Infect Immun (2001) 69(6):3685-91. doi:10.1128/ IAI.69.6.3685-3691.2001

92. Cox DL, Chang P, McDowall AW, Radolf JD. The outer membrane, not a coat of host proteins, limits antigenicity of virulent Treponema pallidum. Infect Immun (1992) 60(3):1076-83.

93. Bunikis J, Barbour AG. Access of antibody or trypsin to an integral outer membrane protein (P66) of Borrelia burgdorferi is hindered by Osp lipoproteins. Infect Immun (1999) 67(6):2874-83.

94. Hinnebusch BJ, Barbour AG, Restrepo BI, Schwan TG. Population structure of the relapsing fever spirochete Borrelia hermsii as indicated by 
polymorphism of two multigene families that encode immunogenic outer surface lipoproteins. Infect Immun (1998) 66(2):432-40.

95. Zhang JR, Norris SJ. Genetic variation of the Borrelia burgdorferi gene vlsE involves cassette-specific, segmental gene conversion. Infect Immun (1998) 66(8):3698-704.

96. Zhang JR, Norris SJ. Kinetics and in vivo induction of genetic variation of vlsE in Borrelia burgdorferi. Infect Immun (1998) 66(8):3689-97.

97. Rogovskyy AS, Bankhead T. Variable VlsE is critical for host reinfection by the Lyme disease spirochete. PLoS One (2013) 8(4):e61226. doi:10.1371/ journal.pone. 0061226

98. Vidal V, Cutler S, Scragg IG, Wright DJ, Kwiatkowski D. Characterisation of silent and active genes for a variable large protein of Borrelia recurrentis. BMC Infect Dis (2002) 2:25. doi:10.1186/1471-2334-2-25

99. Schwan TG, Hinnebusch BJ. Bloodstream- versus tick-associated variants of a relapsing fever bacterium. Science (1998) 280(5371):1938-40. doi:10.1126/ science. 280.5371 .1938

100. Carter CJ, Bergström S, Norris SJ, Barbour AG. A family of surface-exposed proteins of 20 kilodaltons in the genus Borrelia. Infect Immun (1994) 62(7):2792-9.

101. Dennis VA, Dixit S, O’Brien SM, Alvarez X, Pahar B, Philipp MT. Live Borrelia burgdorferi spirochetes elicit inflammatory mediators from human monocytes via the toll-like receptor signaling pathway. Infect Immun (2009) 77(3):1238-45. doi:10.1128/IAI.01078-08

102. Bolz DD, Sundsbak RS, Ma Y, Akira S, Kirschning CJ, Zachary JF, et al. MyD88 plays a unique role in host defense but not arthritis development in Lyme disease. J Immunol (2004) 173(3):2003-10. doi:10.4049/jimmunol.173.3.2003

103. Benhnia MR, Wroblewski D, Akhtar MN, Patel RA, Lavezzi W, Gangloff SC, et al. Signaling through CD14 attenuates the inflammatory response to Borrelia burgdorferi, the agent of Lyme disease. JImmunol (2005) 174(3):1539-48. doi:10.4049/jimmunol.174.3.1539

104. Wang G, Ma Y, Buyuk A, McClain S, Weis JJ, Schwartz I. Impaired host defense to infection and toll-like receptor 2-independent killing of Borrelia burgdorferi clinical isolates in TLR2-deficient C3H/HeJ mice. FEMS Microbiol Lett (2004) 231(2):219-25. doi:10.1016/S0378-1097(03)00960-1

105. Wooten RM, Ma Y, Yoder RA, Brown JP, Weis JH, Zachary JF, et al. Toll-like receptor 2 is required for innate, but not acquired, host defense to Borrelia burgdorferi. J Immunol (2002) 168(1):348-55. doi:10.4049/ jimmunol.168.1.348

106. Wooten RM, Weis JJ. Host-pathogen interactions promoting inflammatory Lyme arthritis: use of mouse models for dissection of disease processes. Curr Opin Microbiol (2001) 4(3):274-9. doi:10.1016/S1369-5274(00)00202-2

107. Lien E, Sellati TJ, Yoshimura A, Flo TH, Rawadi G, Finberg RW, et al. Toll-like receptor 2 functions as a pattern recognition receptor for diverse bacterial products. JBiol Chem (1999) 274(47):33419-25. doi:10.1074/ jbc.274.47.33419

108. Schröder NW, Diterich I, Zinke A, Eckert J, Draing C, von Baehr V, et al. Heterozygous Arg753Gln polymorphism of human TLR-2 impairs immune activation by Borrelia burgdorferi and protects from late stage Lyme disease. J Immunol (2005) 175(4):2534-40. doi:10.4049/jimmunol.175.4.2534

109. Bas S, James RW, Gabay C. Serum lipoproteins attenuate macrophage activation and toll-like receptor stimulation by bacterial lipoproteins. BMC Immunol (2010) 11:46. doi:10.1186/1471-2172-11-46

110. Cullen PA, Haake DA, Adler B. Outer membrane proteins of pathogenic spirochetes. FEMS Microbiol Rev (2004) 28(3):291-318. doi:10.1016/ j.femsre.2003.10.004

111. Schwan TG, Piesman J, Golde WT, Dolan MC, Rosa PA. Induction of an outer surface protein on Borrelia burgdorferi during tick feeding. Proc Natl Acad Sci U S A (1995) 92(7):2909-13. doi:10.1073/pnas.92.7.2909

112. Wilder HK, Raffel SJ, Barbour AG, Porcella SF, Sturdevant DE, Vaisvil B, et al. Transcriptional profiling the $150 \mathrm{~kb}$ linear megaplasmid of Borrelia turicatae suggests a role in vector colonization and initiating mammalian infection. PLoS One (2016) 11(2):e0147707. doi:10.1371/journal.pone.0147707

113. Biesert L, Scheuer W, Bessler WG. Interaction of mitogenic bacterial lipoprotein and a synthetic analogue with mouse lymphocytes. Isolation and characterization of binding proteins. Eur J Biochem (1987) 162(3):651-7. doi :10.1111/j.1432-1033.1987.tb10687.x

114. Bessler WG, Cox M, Lex A, Suhr B, Wiesmüller KH, Jung G. Synthetic lipopeptide analogs of bacterial lipoprotein are potent polyclonal activators for murine B lymphocytes. J Immunol (1985) 135(3):1900-5.
115. Hoffmann P, Heinle S, Schade UF, Loppnow H, Ulmer AJ, Flad HD, et al. Stimulation of human and murine adherent cells by bacterial lipoprotein and synthetic lipopeptide analogues. Immunobiology (1988) 177(2):158-70. doi:10.1016/S0171-2985(88)80036-6

116. Radolf JD, Norgard MV, Schulz WW. Outer membrane ultrastructure explains the limited antigenicity of virulent Treponema pallidum. Proc Natl Acad Sci U S A (1989) 86(6):2051-5. doi:10.1073/pnas.86.6.2051

117. Patel S. Drivers of bacterial genomes plasticity and roles they play in pathogen virulence, persistence and drug resistance. Infect Genet Evol (2016) 45:151-64. doi:10.1016/j.meegid.2016.08.030

118. Norris SJ. vls antigenic variation systems of Lyme disease Borrelia: eluding host immunity through both random, segmental gene conversion and framework heterogeneity. Microbiol Spectr (2014) 2(6). doi:10.1128/microbiolspec. MDNA3-0038-2014

119. Raffel SJ, Battisti JM, Fischer RJ, Schwan TG. Inactivation of genes for antigenic variation in the relapsing fever spirochete Borrelia hermsii reduces infectivity in mice and transmission by ticks. PLoS Pathog (2014) 10(4):e1004056. doi:10.1371/journal.ppat.1004056

120. Magunda PR, Bankhead T. Investigating the potential role of non-vls genes on linear plasmid 28-1 in virulence and persistence by Borrelia burgdorferi. BMC Microbiol (2016) 16(1):180. doi:10.1186/s12866-016-0806-4

121. Wilske B, Barbour AG, Bergström S, Burman N, Restrepo BI, Rosa PA, et al. Antigenic variation and strain heterogeneity in Borrelia spp. Res Microbiol (1992) 143(6):583-96. doi:10.1016/0923-2508(92)90116-6

122. Tilly K, Bestor A, Rosa PA. Functional equivalence of OspA and OspB, but not OspC, in tick colonization by Borrelia burgdorferi. Infect Immun (2016) 84(5):1565-73. doi:10.1128/IAI.00063-16

123. Pretre G, Lapponi MJ, Atzingen MV, Schattner M, Nascimento AL, Gómez RM. Characterization of LIC11207, a novel leptospiral protein that is recognized by human convalescent sera and prevents apoptosis of polymorphonuclear leukocytes. Microb Pathog (2013) 56:21-8. doi:10.1016/j. micpath.2012.10.002

124. Skerka C, Zipfel PF. Complement factor $\mathrm{H}$ related proteins in immune diseases. Vaccine (2008) 26(Suppl 8):19-14. doi:10.1016/j.vaccine.2008. 11.021

125. Garcia BL, Zhi H, Wager B, Höök M, Skare JT. Borrelia burgdorferi BBK32 inhibits the classical pathway by blocking activation of the $\mathrm{C} 1$ complement complex. PLoS Pathog (2016) 12(1):e1005404. doi:10.1371/journal. ppat.1005404

126. von Lackum K, Miller JC, Bykowski T, Riley SP, Woodman ME, Brade V, et al. Borrelia burgdorferi regulates expression of complement regulator-acquiring surface protein 1 during the mammal-tick infection cycle. Infect Immun (2005) 73(11):7398-405. doi:10.1128/IAI.73.11.7398-7405.2005

127. Kraiczy P, Skerka C, Kirschfink M, Brade V, Zipfel PF. Immune evasion of Borrelia burgdorferi by acquisition of human complement regulators FHL-1/reconectin and factor H. Eur JImmunol (2001) 31(6):1674-84. doi:10.1002/1521-4141(200106)31:6<1674::AID-IMMU1674>3.0.CO;2-2

128. Alitalo A, Meri T, Comstedt P, Jeffery L, Tornberg J, Strandin T, et al. Expression of complement factor $\mathrm{H}$ binding immunoevasion proteins in Borrelia garinii isolated from patients with neuroborreliosis. Eur J Immunol (2005) 35(10):3043-53. doi:10.1002/eji.200526354

129. Schmidt CQ, Kennedy AT, Tham WH. More than just immune evasion: hijacking complement by Plasmodium falciparum. Mol Immunol (2015) 67(1):71-84. doi:10.1016/j.molimm.2015.03.006

130. Mallevaey T, Selvanantham T. Strategy of lipid recognition by invariant natural killer T cells: 'one for all and all for one'. Immunology (2012) 136(3):273-82. doi:10.1111/j.1365-2567.2012.03580.x

131. Bulut Y, Faure E, Thomas L, Equils O, Arditi M. Cooperation of toll-like receptor 2 and 6 for cellular activation by soluble tuberculosis factor and Borrelia burgdorferi outer surface protein A lipoprotein: role of toll-interacting protein and IL-1 receptor signaling molecules in toll-like receptor 2 signaling. J Immunol (2001) 167(2):987-94.

132. Hsu SH, Lo YY, Tung JY, Ko YC, Sun YJ, Hung CC, et al. Leptospiral outer membrane lipoprotein LipL32 binding on toll-like receptor 2 of renal cells as determined with an atomic force microscope. Biochemistry (2010) 49(26):5408-17. doi:10.1021/bi100058w

133. Grassmann AA, Félix SR, dos Santos CX, Amaral MG, Seixas Neto AC, Fagundes MQ, et al. Protection against lethal leptospirosis after vaccination with LipL32 coupled or coadministered with the B subunit of Escherichia 
coli heat-labile enterotoxin. Clin Vaccine Immunol (2012) 19(5):740-5. doi:10.1128/CVI.05720-11

134. Luo D, Xue F, Ojcius DM, Zhao J, Mao Y, Li L, et al. Protein typing of major outer membrane lipoproteins from Chinese pathogenic Leptospira spp. and characterization of their immunogenicity. Vaccine (2009) 28(1):243-55. doi:10.1016/j.vaccine.2009.09.089

135. Rossmann E, Kraiczy P, Herzberger P, Skerka C, Kirschfink M, Simon MM, et al. Dual binding specificity of a Borrelia hermsii-associated complement regulator-acquiring surface protein for factor $\mathrm{H}$ and plasminogen discloses a putative virulence factor of relapsing fever spirochetes. J Immunol (2007) 178(11):7292-301. doi:10.4049/jimmunol.178.11.7292

136. Hellwage J, Meri T, Heikkilä T, Alitalo A, Panelius J, Lahdenne P, et al. The complement regulator factor $\mathrm{H}$ binds to the surface protein OspE of Borrelia burgdorferi. J Biol Chem (2001) 276(11):8427-35. doi:10.1074/jbc. M007994200

137. Guo BP, Brown EL, Dorward DW, Rosenberg LC, Höök M. Decorin-binding adhesins from Borrelia burgdorferi. Mol Microbiol (1998) 30(4):711-23. doi:10.1046/j.1365-2958.1998.01103.x

138. Hauk P, Macedo F, Romero EC, Vasconcellos SA, de Morais ZM, Barbosa AS, et al. In LipL32, the major leptospiral lipoprotein, the $\mathrm{C}$ terminus is the primary immunogenic domain and mediates interaction with collagen IV and plasma fibronectin. Infect Immun (2008) 76(6):2642-50. doi:10.1128/ IAI.01639-07

139. Choy HA, Kelley MM, Chen TL, Møller AK, Matsunaga J, Haake DA. Physiological osmotic induction of Leptospira interrogans adhesion: LigA and LigB bind extracellular matrix proteins and fibrinogen. Infect Immun (2007) 75(5):2441-50. doi:10.1128/IAI.01635-06

140. Hovis KM, Jones JP, Sadlon T, Raval G, Gordon DL, Marconi RT. Molecular analyses of the interaction of Borrelia hermsii FhbA with the complement regulatory proteins factor $\mathrm{H}$ and factor $\mathrm{H}$-like protein 1. Infect Immun (2006) 74(4):2007-14. doi:10.1128/IAI.74.4.2007-2014.2006

141. Bankhead T, Chaconas G. The role of VlsE antigenic variation in the Lyme disease spirochete: persistence through a mechanism that differs from other pathogens. Mol Microbiol (2007) 65(6):1547-58. doi:10.1111/j.1365-2958.2007.05895.x

142. Grosskinsky S, Schott M, Brenner C, Cutler SJ, Simon MM, Wallich R. Human complement regulators $\mathrm{C} 4 \mathrm{~b}$-binding protein and $\mathrm{C} 1$ esterase inhibitor interact with a novel outer surface protein of Borrelia recurrentis. PLoS Negl Trop Dis (2010) 4(6):e698. doi:10.1371/journal.pntd.0000698

143. Werts C, Tapping RI, Mathison JC, Chuang TH, Kravchenko V, Saint Girons I, et al. Leptospiral lipopolysaccharide activates cells through a TLR2-dependent mechanism. Nat Immunol (2001) 2(4):346-52. doi:10.1038/86354

144. Haake DA, Mazel MK, McCoy AM, Milward F, Chao G, Matsunaga J, et al. Leptospiral outer membrane proteins OmpL1 and LipL41 exhibit synergistic immunoprotection. Infect Immun (1999) 67(12):6572-82.

145. Verma A, Artiushin S, Matsunaga J, Haake DA, Timoney JF. LruA and LruB, novel lipoproteins of pathogenic Leptospira interrogans associated with equine recurrent uveitis. Infect Immun (2005) 73(11):7259-66. doi:10.1128/ IAI.73.11.7259-7266.2005

146. Verma A, Rathinam SR, Priya CG, Muthukkaruppan VR, Stevenson B, Timoney JF. LruA and LruB antibodies in sera of humans with leptospiral uveitis. Clin Vaccine Immunol (2008) 15(6):1019-23. doi:10.1128/CVI.00203-07

147. Brown JP, Zachary JF, Teuscher C, Weis JJ, Wooten RM. Dual role of interleukin-10 in murine Lyme disease: regulation of arthritis severity and host defense. Infect Immun (1999) 67(10):5142-50.

148. Fikrig E, Feng W, Barthold SW, Telford SR III, Flavell RA. Arthropod- and host-specific Borrelia burgdorferi bbk32 expression and the inhibition of spirochete transmission. J Immunol (2000) 164(10):5344-51. doi:10.4049/ jimmunol.164.10.5344

149. Wang J, Li Y, Kinjo Y, Mac TT, Gibson D, Painter GF, et al. Lipid binding orientation within CD1d affects recognition of Borrelia burgorferi antigens by NKT cells. Proc Natl Acad Sci U S A (2010) 107(4):1535-40. doi:10.1073/ pnas.0909479107

150. Cruz AR, Ramirez LG, Zuluaga AV, Pillay A, Abreu C, Valencia CA, et al. Immune evasion and recognition of the syphilis spirochete in blood and skin of secondary syphilis patients: two immunologically distinct compartments. PLoS Negl Trop Dis (2012) 6(7):e1717. doi:10.1371/journal.pntd.0001717

151. BenMohamed L, Wechsler SL, Nesburn AB. Lipopeptide vaccines - yesterday, today, and tomorrow. Lancet Infect Dis (2002) 2(7):425-31. doi:10.1016/ S1473-3099(02)00318-3

152. Melo R, Richer L, Johnson DL, Gomes-Solecki M. Oral immunization with OspC does not prevent tick-borne Borrelia burgdorferi infection. PLoS One (2016) 11(3):e0151850. doi:10.1371/journal.pone.0151850

153. Lourdault K, Wang LC, Vieira A, Matsunaga J, Melo R, Lewis MS, et al. Oral immunization with Escherichia coli expressing a lipidated form of LigA protects hamsters against challenge with Leptospira interrogans serovar Copenhageni. Infect Immun (2014) 82(2):893-902. doi:10.1128/IAI.01533-13

154. del Rio B, Seegers JF, Gomes-Solecki M. Immune response to Lactobacillus plantarum expressing Borrelia burgdorferi OspA is modulated by the lipid modification of the antigen. PLoS One (2010) 5(6):e11199. doi:10.1371/ journal.pone.0011199

155. Skwarczynski M, Toth I. Lipid-core-peptide system for self-adjuvanting synthetic vaccine delivery. Methods Mol Biol (2011) 751:297-308. doi:10.1007/978-1-61779-151-2_18

156. Jackson DC, Lau YF, Le T, Suhrbier A, Deliyannis G, Cheers C, et al. A totally synthetic vaccine of generic structure that targets toll-like receptor 2 on dendritic cells and promotes antibody or cytotoxic T cell responses. Proc Natl Acad Sci U S A (2004) 101(43):15440-5. doi:10.1073/pnas.0406740101

157. Salverda ML, Meinderts SM, Hamstra HJ, Wagemakers A, Hovius JW, van der Ark A, et al. Surface display of a borrelial lipoprotein on meningococcal outer membrane vesicles. Vaccine (2016) 34(8):1025-33. doi:10.1016/j. vaccine.2016.01.019

158. Leng CH, Liu SJ, Chen HW, Chong P. Recombinant bacterial lipoproteins as vaccine candidates. Expert Rev Vaccines (2015) 14(12):1623-32. doi:10.1586 /14760584.2015.1091732

159. Zom GG, Khan S, Filippov DV, Ossendorp F. TLR ligand-peptide conjugate vaccines: toward clinical application. Adv Immunol (2012) 114:177-201. doi:10.1016/B978-0-12-396548-6.00007-X

160. Kelesidis T. The interplay between daptomycin and the immune system. Front Immunol (2014) 5:52. doi:10.3389/fimmu.2014.00052

161. Feng J, Auwaerter PG, Zhang Y. Drug combinations against Borrelia burgdorferi persisters in vitro: eradication achieved by using daptomycin, cefoperazone and doxycycline. PLoS One (2015) 10(3):e0117207. doi:10.1371/journal. pone. 0117207

Conflict of Interest Statement: The authors declare that the research was conducted in the absence of any commercial or financial relationships that could be construed as a potential conflict of interest.

Copyright (c) 2017 Christodoulides, Boyadjian and Kelesidis. This is an open-access article distributed under the terms of the Creative Commons Attribution License (CC $B Y)$. The use, distribution or reproduction in other forums is permitted, provided the original author(s) or licensor are credited and that the original publication in this journal is cited, in accordance with accepted academic practice. No use, distribution or reproduction is permitted which does not comply with these terms. 